\title{
Fishery biology of the jumbo flying squid Dosidicus gigas off the Exclusive Economic Zone of Chilean waters
}

\author{
BILIN LIU ${ }^{1}$, XINJUN CHEN ${ }^{1,2,3}$, HUAJIE LU ${ }^{1}$, YONG CHEN ${ }^{4,1}$ and WEIGUO QIAN ${ }^{1,2,3}$ \\ ${ }^{1}$ College of Marine Sciences, Shanghai Ocean University,Hucheng Ring Road 999, Lingang New City, Shanghai, \\ China, 201306. E-mail: xjchen@ shou.edu.cn \\ ${ }^{2}$ The Key Laboratory of Shanghai Education Commission for Oceanic Fisheries Resources Exploitation, \\ 999 Hucheng Ring Road, Shanghai 201306, China. \\ ${ }^{3}$ The Key Laboratory of Sustainable Exploitation of Oceanic Fisheries Resources, Ministry of Education, \\ 999 Hucheng Ring Road, Shanghai 201306, China. \\ ${ }^{4}$ School of Marine Sciences, University of Maine, Orono, Maine 04469, USA.
}

\begin{abstract}
SUMMARY: The jumbo flying squid Dosidicus gigas is widely distributed in the eastern Pacific Ocean and supports an important fishery. Although many studies have been carried out on the biology of this species, limited biological information is available in the waters outside the Exclusive Economic Zone of Chile (EEZ) $\left(20^{\circ} \mathrm{S}-41^{\circ} \mathrm{S}\right.$ and $\left.74^{\circ} 30^{\prime} \mathrm{W}-84^{\circ} \mathrm{W}\right)$. Three surveys were conducted in this area by the Chinese squid jigging vessels during the period from April 2006 to May 2008. The majority of the catch in the survey was from the two areas defined by $37^{\circ} 30^{\prime}-41^{\circ} \mathrm{S}$ and $78^{\circ} 30^{\prime}-80^{\circ} \mathrm{W}$ and by $25^{\circ}-30^{\circ} \mathrm{S}$ and $76^{\circ}-77^{\circ} 30^{\prime} \mathrm{W}$. The sex ratio (M: F) of the catch was $1: 2.48$. The mean mantle length (ML) was $376 \mathrm{~mm}$ for males with a range of $257-721 \mathrm{~mm}$ and $388.7 \mathrm{~mm}$ for females with a range of $236-837 \mathrm{~mm}$. Two distinguished size classes, medium- and large-sized groups, were identified in this study with the medium-sized group (350-450 mm ML) consisting of $89 \%$ of the total catch. The sizes at first sexual maturity were $638 \mathrm{~mm}$ ML for females and $565 \mathrm{~mm}$ ML for males. This study suggests that all the individuals examined were hatched from March 2007 to February 2008, indicating that D. gigas might spawn all year around with a peak spawning time from November 2007 to January 2008. Most of the stomachs analyzed had food remains. The preys included three major groups: fish (mainly lanternfish), cephalopods and crustaceans, but D. gigas was the dominant species in the stomach contents, showing strong evidence of cannibalism. The information obtained from this study improves our understanding of the fishery biology of D. gigas off Chile.
\end{abstract}

Keywords: Dosidicus gigas, fishery biology, Chile.

RESUMEN: Biología Pesquera de la pota gigante Dosidicus gigas en aguas exteriores a la Zona Económica ExClusiva DE CHILE. - La pota gigante Dosidicus gigas está ampliamente distribuida en el océano Pacífico oriental y soporta una pesquería importante. Aunque se han realizado muchos estudios sobre la biología de esta especie, la información existente para aguas externas a la Zona Económica Exclusiva (ZEE) de Chile $\left(20^{\circ} \mathrm{S}-41^{\circ} \mathrm{S}\right.$ y $\left.74^{\circ} 30^{\prime} \mathrm{W}-84^{\circ} \mathrm{W}\right)$ es muy limitada. Los barcos poteros chinos realizaron tres campañas en esta área entre abril de 2006 y mayo de 2008. La mayoría de las capturas en esas campañas proceden de dos áreas definidas por las coordenadas $37^{\circ} 31^{\prime} \mathrm{S}-41^{\circ} \mathrm{S} 78^{\circ} 30^{\prime} \mathrm{W}-80^{\circ} \mathrm{W}$ y $25^{\circ} \mathrm{S}-30^{\circ} \mathrm{S}$ $76^{\circ} \mathrm{W}-77^{\circ} 30^{\prime} \mathrm{W}$, respectivamente. La relación sexual $(\mathrm{M}: \mathrm{H})$ en las capturas fue de 1:2.48. La longitud media del manto (LM) fue de $376 \mathrm{~mm}$ para los machos con un rango que varió entre 257 y $721 \mathrm{~mm}$, y de $388.7 \mathrm{~mm}$ para las hembras $(236-837 \mathrm{~mm})$. Se diferenciaron dos clases de tamaño: un grupo medio, cuya LM varió entre 350 y $450 \mathrm{~mm}$ representando un $89 \%$ de la captura total, y un grupo grande. La talla de primera maduración sexual fue de $638 \mathrm{~mm}$ para las hembras y de $565 \mathrm{~mm}$ para los machos. Este trabajo sugiere que todos los individuos examinados habían nacido entre marzo de 2007 y febrero de 2008, lo cual indica que $D$. gigas puede frezar durante todo el año, habiendo existido un pico de puesta desde noviembre de 2007 hasta enero de 2008. La mayoría de los estómagos analizados contenían restos. Las presas incluyen tres grandes grupos de organismos: peces (principalmente mictófidos), cefalópodos y crustáceos. Sin embargo, D. gigas fue la presa dominate en los contenidos estomacales, lo cual es una evidencia del fuerte canibalismo existente en esta especie. La información que se deriva de este trabajo mejora nuestro conocimiento sobre la biología de D. gigas frente a Chile.

Palabras clave: Dosidicus gigas, biología pesquera, Chile. 


\section{INTRODUCTION}

The jumbo flying squid (Dosidicus gigas d'Orbigny, 1835 ) is widely distributed in the eastern Pacific Ocean from California $\left(37^{\circ} \mathrm{N}\right)$ to southern Chile $\left(47^{\circ} \mathrm{S}\right)$, and the maximum longitudinal distribution is reached eastwards up to $125^{\circ} \mathrm{W}$ at the equator (Nesis, 1983; Nigmatullin et al., 2001). The highest concentrations in the southern and northern hemispheres have been observed off the Peruvian coast and the Gulf of California, respectively (Wang and Chen, 2005; Keyl et al., 2008). D. gigas supports one of the most important cephalopod fisheries in the eastern Pacific Ocean. The D. gigas landings are mainly from Peru, Mexico and Chile, and reached 291-435 thousand t, 53-66 thousand t, and 122-297 thousand t, respectively, from 2005 to 2007. The squid jigging fleet from China, Japan and South Korea also targeted D. gigas stock with a total annual landing of 55122 thousand t from 2005 to 2007 (http://www.fao.org/ fishery/statistics/global-capture-production/query/en).

Many studies have been carried out on the fisheries biology of D. gigas in the Gulf of California and off the Peruvian coast (Nigmatullin et al., 2001; Chen et al., 2008). These studies suggest that the population structure is complicated, consisting of three groups with a different mantle length (ML) at maturity. These three groups include a small group with an ML at maturity of $130-260 \mathrm{~mm}$ and $140-340 \mathrm{~mm}$ for males and females, respectively, which are predominantly present in the equatorial area; a medium-sized group with an ML at maturity of $240-420 \mathrm{~mm}$ and $280-600 \mathrm{~mm}$ for males and females, respectively, which occur over the whole species range; and a large size group with an ML at maturity of $>400-500 \mathrm{~mm}$ and $>550-650 \mathrm{~mm}$ for males and females, respectively, which occur in the northern and southern peripheries of the range (Nesis, 1983; Nigmatullin et al., 2001).

Zúniga et al. (2008) postulated the existence of two reproductive cycles for $D$. gigas based on the regular pattern of periodicity in the monthly catch of D. gigas along the Chilean coast during the period from 2002 to 2005. The life spans of all three groups are about 1 year, but the largest individuals of the large group can probably live for 2 years (Nigmatullin et al., 2001; Hu et al., 2009).

Statolith ageing studies generally confirmed high growth rates of $D$. gigas, which could attain large sizes in less than 1 year. A mature female of $720 \mathrm{~mm}$ ML had an increment of $345 \mathrm{~mm}$ in its statoliths (Arkhipkin, 1989), a $770 \mathrm{~mm}$ ML male and a $860 \mathrm{~mm}$ ML female had an increment of $52 \mathrm{~mm}$ and $338 \mathrm{~mm}$, respectively (Masuda et al., 1998; Argüelles et al., 2001).

Wormuth (1970) also showed large geographical variations in size composition for D. gigas. Individuals larger than $400 \mathrm{~mm}$ ML are rarely found to the north of the equator, while to the south they can reach a size of more than $1000 \mathrm{~mm}$ ML. Off the Chilean coasts, GarciaTello (1965) found D. gigas of up to $930 \mathrm{~mm}$ ML. In the high sea $\left(5-16^{\circ} \mathrm{S}\right.$ and $\left.79-90^{\circ} \mathrm{W}\right)$ off Peru from June to August, the ML of catch ranged from 203 to $805 \mathrm{~mm}$ and the dominant ML was between 240 and $480 \mathrm{~mm}$, accounting for $80 \%$ of the total catch (Ye, 2002).

Spawning takes place throughout the year, but with a distinct peak in spring and summer in the southern hemisphere (October-January; Tafur et al., 2001). D. gigas are monocyclic and have the highest potential fecundity of all the cephalopods, up to 32 million oocytes (Nigmatullin, 1999). In the Gulf of California, the large female D. gigas mature at $750 \mathrm{~mm} \mathrm{ML}$ and males mature at two sizes, $530 \mathrm{~mm}$ and $670 \mathrm{~mm}$ ML. A medium-sized mature group is identified: $400 \mathrm{~mm}$ ML for females and $330 \mathrm{~mm}$ ML for males (Markaida and Sosa-Nishizaki, 2003). In the open waters off Peru, the male D. gigas are found to mature at younger ages than the females. Argüelles et al. (2008) also examined changes in the size-at-maturity of female D. gigas off the Peruvian coast during the period from1989 to 2004. The initial size at sexual maturity was estimated to be $374 \mathrm{~mm}$ ML for females and $228 \mathrm{~mm}$ ML for males (Ye and Chen, 2007).

D. gigas is an active predator (Nesis, 1983; Wang and Chen, 2005). The common prey species include copepods, hyperiid amphipods, euphausiids, pelagic shrimps and red crabs (Pleuroncodes planipes), heteropod molluscs, squid, pelagic octopods and various finfishes (Ehrhard et al., 1983; Bazanov, 1987; Nigmatullin et al., 2001; Markaida, 2006). The most common finfish preys are epipelagic lanternfish, and squid prey species are ommastrephids, including D. gigas (Nigmatullin et al., 2001).

In Chilean waters, D. gigas are highly abundant and support one of the most important fisheries in recent years (Rocha, 1997; Zúñiga et al., 2008). Rocha and Vega (2003) reported that D. gigas were landed yearround, mainly concentrated in waters off central Chile. Ibáñez and Cubillos (2007) described the spatial and seasonal changes in the size structure and reproductive activity of D. gigas in the central-southern area off Chile $\left(34-40^{\circ} \mathrm{S}\right)$. Little information is, however, available on the fishery biology of D. gigas in the waters outside the Exclusive Economic Zone (EEZ) of Chile (south of $20^{\circ} \mathrm{S}$ ).

This study evaluates the fishery biology of D. gigas based on data collected in the three scientific surveys for $D$. gigas undertaken by the Chinese squid jigger vessels from 2006 to 2008 in waters outside the EEZ of Chile. We present information on the spatial distribution of catch, population structure, maturity, age and feeding, which is critical in our understanding of the life history and population dynamics of $D$. gigas off Chile. The study fills a knowledge gap in fishery biology of $D$. gigas in an area not covered in previous studies.

\section{MATERIALS AND METHODS}

The surveys were conducted by the three Chinese squid jiggers New Century No 52, Xin Jieli No 8 and Zhe Yunyu No 807 (Table 1). The survey area is de- 
TABLE 1. - The key parameters of the three squid jigging vessels used in this study.

\begin{tabular}{|c|c|c|c|}
\hline Key vessel parameters & $\begin{array}{c}\text { New Century } \\
\text { No } 52\end{array}$ & $\begin{array}{l}\text { Xin Jieli } \\
\text { No } 8\end{array}$ & $\begin{array}{c}\text { Zhe Yunyu } \\
\text { No } 807\end{array}$ \\
\hline Total length & $64.00 \mathrm{~m}$ & $60.85 \mathrm{~m}$ & $54.3 \mathrm{~m}$ \\
\hline Gross register tonnage & $1336 \mathrm{t}$ & $1168 \mathrm{t}$ & $432 \mathrm{t}$ \\
\hline Number of squid jigging machines & 46 & 47 & 38 \\
\hline Power of fishing lights & $160 \times 2 \mathrm{KW}$ & $120 \times 2 \mathrm{KW}$ & $130 \times 1 \mathrm{KW}$ \\
\hline
\end{tabular}

TABLE 2. - Summary of the survey areas and sample collection of Dosidicus gigas between April 2006 and May 2008.

\begin{tabular}{|c|c|c|c|c|c|c|}
\hline Survey date & Vessel & Survey area & $\begin{array}{l}\text { Planned } \\
\text { station }\end{array}$ & $\begin{array}{l}\text { Fishing } \\
\text { station }\end{array}$ & $\begin{array}{l}\text { Number } \\
\text { of samples }\end{array}$ & $\begin{array}{l}\text { Range of } \\
\text { mantle } \\
\text { length }(\mathrm{mm})\end{array}$ \\
\hline Apr.-Jul. 2006 & $\begin{array}{l}\text { New Century No 52; } \\
\text { Xin Jieli No } 8\end{array}$ & $\begin{array}{l}26^{\circ} \mathrm{S}-30^{\circ} \mathrm{S} \text { and } 76^{\circ} \mathrm{W}-78^{\circ} \mathrm{W} ; \\
37^{\circ} 30^{\prime} \mathrm{S}-41^{\circ} 00^{\prime} \mathrm{S} \text { and } 78^{\circ} 30^{\prime} \mathrm{W}-84^{\circ} \mathrm{W}\end{array}$ & 95 & 101 & 1013 & $236-549$ \\
\hline $\begin{array}{l}\text { Nov. 2006-Jan. } 2007 \\
\text { and May-Jul. } 2007\end{array}$ & $\begin{array}{l}\text { New Century No } 52 \\
\text { Xin Jieli No } 8\end{array}$ & $\begin{array}{l}22^{\circ}-30^{\circ} 30^{\prime} \mathrm{S} \text { and } 75^{\circ} 30^{\prime}-78^{\circ} \mathrm{W} \\
37^{\circ} 30^{\prime} \mathrm{S}-41^{\circ} 00^{\prime} \mathrm{S} \text { and } 78^{\circ} 30^{\prime}-82^{\circ} \mathrm{W}\end{array}$ & 124 & 130 & 430 & $287-702$ \\
\hline Jan.-Mar. and May 2008 & $\begin{array}{l}\text { New Century No } 52 \\
\text { Zhe Yunyu No } 807\end{array}$ & $20^{\circ}-24^{\circ} 30^{\prime} \mathrm{S}$ and $74^{\circ} 30^{\prime}-82^{\circ} \mathrm{W}$ & 120 & 121 & 635 & $270-837$ \\
\hline
\end{tabular}

scribed in Table 2 . Fishing stations were pre-selected and defined by $30^{\prime} \times 30^{\prime}$ longitude and latitude before the survey (Fig. 1). The final fishing positions were defined as the actual sites where D. gigas were caught. Samples were randomly taken from the catch and 2078 specimens of both sexes were measured in ML to the nearest $1 \mathrm{~mm}$ and in weight to the nearest $10 \mathrm{~g}$. Specimens were sexed and their maturation stages were defined on a scale I-V (Lipinski, 1979). The number of specimens analyzed per station varied depending on the total catch at the station. Fishing position, water temperature and salinity of different water depths from surface to $300 \mathrm{~m}$, number of jig lines in uses ( 8 jiggers per line), fishing depth, time at the beginning and end of each deployment and total catch were recorded.

Statoliths were dissected for D. gigas in the field and stored in $90 \%$ alcohol for age and growth analysis. There were 133 specimens in total for statolith samples with their ML values ranging from 288 to $575 \mathrm{~mm}$. The ageing method followed that described by Arkhipkin (1991). An image analysis system (WT-Tiger 3000) was used for counting rings on both sides of statoliths. For each of these squid, the hatching date was estimated from its age and the date when the squid was caught.

Mantle lengths of the specimens used for diet analysis ranged from 156 to $610 \mathrm{~mm}$. Major preys in the stomach contents were identified based on undissolved tissues in the stomach. The degree of stomach fullness was recorded on the following scales (Chen et al., 2007): 0 , stomach is empty; 1 , there is little content; 2 , stomach is less than half full; 3 , stomach is more than half full; and 4, stomach is full.

The whole body weight-ML relationship and somatic body weight-ML relationship (i.e. excluding offal of squid) were quantified using the equation $\mathrm{W}=$ $\mathrm{aML}^{\mathrm{b}}$, where $\mathrm{W}$ is the whole body weight or somatic body weight. Log transformation was applied to the equation and parameters $a$ and $b$ were estimated using the linear least squares method (Ricker, 1975).

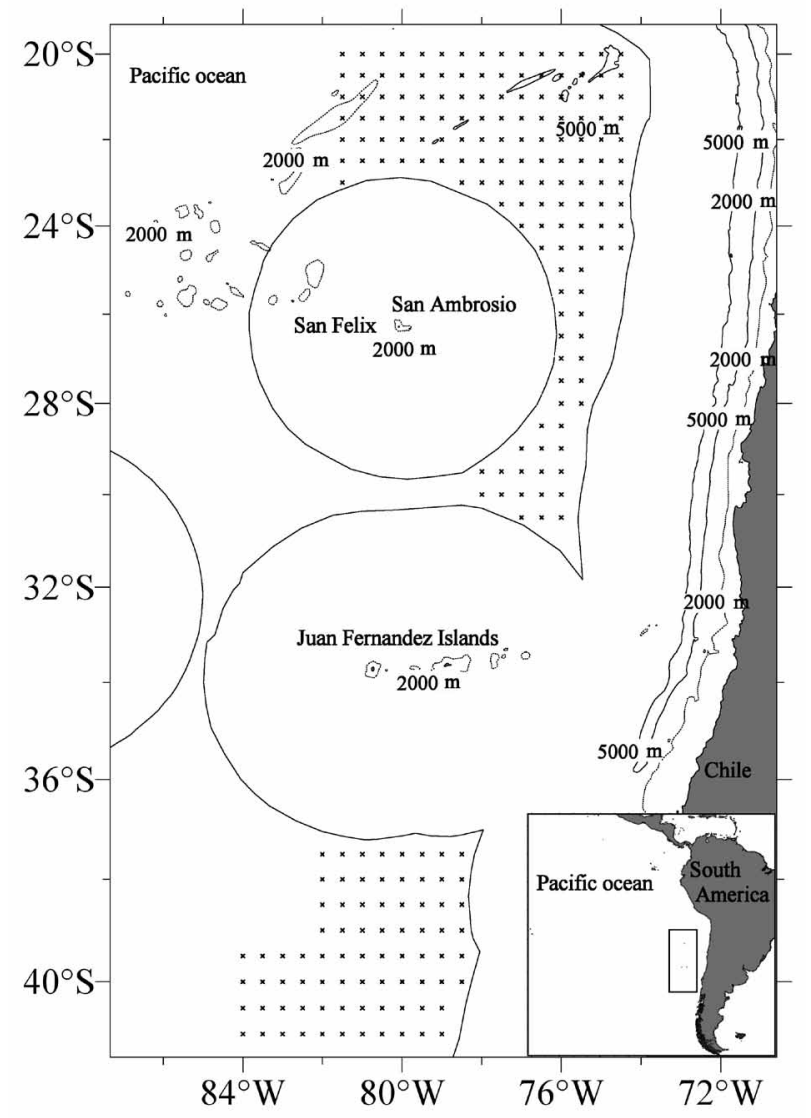

FIG. 1. - Three survey areas covered by the Chinese squid jigger vessels off Chile between April 2006 and May 2008. The constant line and asterisks represent the Exclusive Economic Zone and planned survey stations, respectively.

All sampled male and female individuals were examined for their maturation respectively, and data were used to determine the ML at which $50 \%$ of squid were mature which refers to 'size at first maturity' or ' $\mathrm{ML}_{50 \%}$ '. Changes in the proportion of mature squid 
$690 \cdot$ B. LIU et al.

TABLE 3. - Temperature (T) and salinity (S) of different water depths in the fishing grounds of Dosidicus gigas off Chile.

\begin{tabular}{|c|c|c|c|c|c|c|c|c|c|}
\hline \multirow[t]{2}{*}{ Areas } & \multirow[t]{2}{*}{ Month } & \multicolumn{2}{|c|}{ Surface layer } & \multicolumn{2}{|c|}{$50 \mathrm{~m}$ depth } & \multicolumn{2}{|c|}{100 m depth } & \multicolumn{2}{|c|}{$200 \mathrm{~m}$ depth } \\
\hline & & $\mathrm{T}$ & $\mathrm{S}$ & $\mathrm{T}$ & $\mathrm{S}$ & $\mathrm{T}$ & $\mathrm{S}$ & $\mathrm{T}$ & $\mathrm{S}$ \\
\hline $37^{\circ} 30^{\prime}-41^{\circ} \mathrm{S}$ and & December to January & 14 & $33.91-34.15$ & $13.5-14$ & $33.92-33.95$ & $12-13.5$ & $33.59-33.93$ & 9 & $33.98-34.16$ \\
\hline $78^{\circ} 30^{\prime}-80^{\circ} \mathrm{W}$ & May to July & $14-15.5$ & $33.58-34.23$ & $13.5-14.5$ & $33.14-34.29$ & $10-12$ & $33.82-34.11$ & $8.5-9.5$ & $33.95-34.18$ \\
\hline $25^{\circ}-30^{\circ} \mathrm{S}$ and & April to May & $17.5-19$ & & & & & & & \\
\hline $76^{\circ}-77^{\circ} 30^{\prime} \mathrm{W}$ & June & $17.5-21$ & $34.17-34.71$ & $17-19$ & $34.26-34.79$ & $13-15$ & $33.97-34.28$ & $10-11.5$ & $34.17-34.65$ \\
\hline
\end{tabular}

with ML were fitted to a logistic equation described below using the least squares method:

$$
P_{i}=\frac{1}{1+e^{-\left(c+d M L_{i}\right)}}
$$

where $P_{i}$ is the proportion of mature individuals in length class $M L_{i}, c$ and $d$ are the two parameters to be estimated in the regression analysis, and $M L_{50 \%}=c / d$.

\section{RESULTS}

\section{Catch data, relationship between fishing ground and environmental variables}

The daily catch ranged from 0.1 to $32.0 \mathrm{t} / \mathrm{d} \mathrm{com-}$ posed entirely of $D$. gigas. The total catch was $2745 \mathrm{t}$ during the three surveys, and the average daily catch reached $4.94 \mathrm{t} / \mathrm{d}$. The number of fishing days when the daily catch was lower than $2 \mathrm{t} / \mathrm{d}$ only consisted of $13.59 \%$ of the total fishing days, and the number of days when daily catch was more than $5 \mathrm{t} / \mathrm{d}$ consisted of $68.6 \%$ of the total fishing days. During the three surveys, the catch mainly came from the two areas defined, respectively, by $37^{\circ} 30^{\prime}-41^{\circ} \mathrm{S}$ and $78^{\circ} 30^{\prime}-80^{\circ} \mathrm{W}$, and by $25^{\circ}-30^{\circ} \mathrm{S}$ and $76^{\circ}-77^{\circ} 30^{\prime} \mathrm{W}$ (Fig. 2). High density of D. gigas was found in the above two areas with different environmental conditions (Table 3). On the fishing ground of $37^{\circ} 30^{\prime}-41^{\circ} \mathrm{S}$ and $78^{\circ} 30^{\prime}-80^{\circ} \mathrm{W}$, the temperatures for different depths $(0 \mathrm{~m}, 50 \mathrm{~m}$ and $200 \mathrm{~m}$ ) were $14-15.5^{\circ} \mathrm{C}, 13.5-14.5^{\circ} \mathrm{C}$ and $8.5-9.5^{\circ} \mathrm{C}$, respectively, from December to January and May to July (Table 3 ). On the fishing ground of $25^{\circ}-30^{\circ} \mathrm{S}$ and $76^{\circ}-77^{\circ} 30^{\prime} \mathrm{W}$, the temperatures for different depths $(0$ $\mathrm{m}, 50 \mathrm{~m}$ and $200 \mathrm{~m}$ ) were $17.5-21^{\circ} \mathrm{C}, 17-19^{\circ} \mathrm{C}$ and $10-$ $11.5^{\circ} \mathrm{C}$, respectively, in April, May and June (Table 3 ). The salinity of different water layers in the fishing grounds is also summarized in Table 3 .

\section{Population structure}

In total 1481 female and 597 male D. gigas were randomly sampled and examined. The sex ratios (M:F) for the catch were 1:2.48, 1:2.77 and 1:2.36 for the three surveys, respectively $(\mathrm{P}<0.05)$. The mean ML was 376.0 $\mathrm{mm}$ for sampled males (ranging from 257 to $721 \mathrm{~mm}$ ) and $388.7 \mathrm{~mm}$ for sampled females (ranging from 236 to $837 \mathrm{~mm}$ ). The mean body weight was $1617 \mathrm{~g}$ for males (ranging from 570 to $10940 \mathrm{~g}$ ) and $1887 \mathrm{~g}$ for females (ranging from 350 to $20400 \mathrm{~g}$ ). There was a clear mode from 300 to $450 \mathrm{~mm}$ ML for males and females, account-

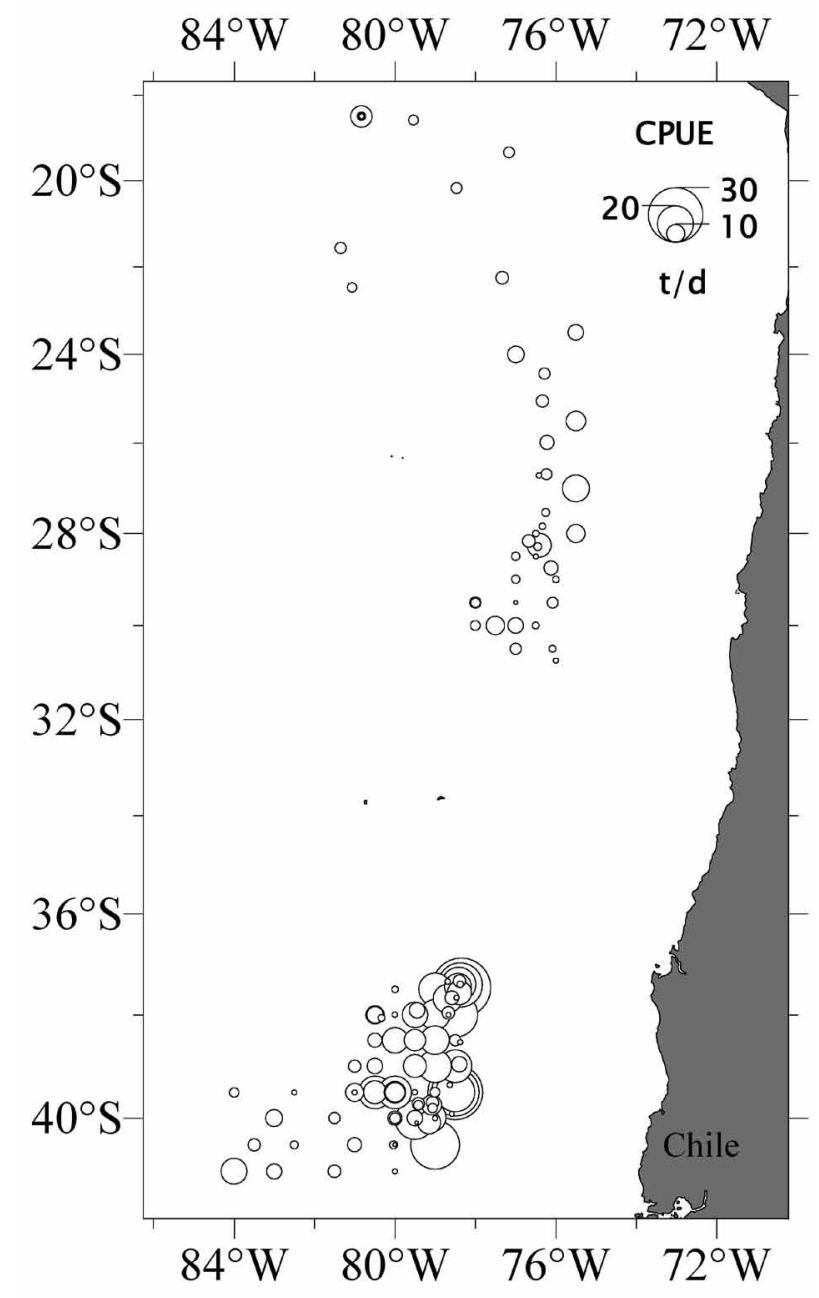

FIG. 2. - Spatial distribution of daily catch of D. gigas in the $0.5^{\circ} \times 0.5^{\circ}$ latitude and longitude off Chile between April 2006 and May 2008.

ing for $89.1 \%$ and $89.3 \%$ of the total catch, respectively (Fig. 3a). There was also a clear mode for the whole body weight (BW) from 1000 to $2000 \mathrm{~g}$ for males and females, accounting for $60.0 \%$ and $65.1 \%$ of the total samples, respectively (Fig. 3b). A less significant mode was observed at $600-700 \mathrm{~mm}$ ML and 9000-11500 g BW for females (Fig. 3a and 3b).

The spatial distributions of size for D. gigas by two-degree longitude and two-degree latitude were analyzed. The spatial distribution in squid size and dominant ML group had greater variability along the latitude $(\mathrm{P}<0.05)$ than that along the longitude $(\mathrm{P}>0.05)$. Between $20^{\circ} \mathrm{S}$ and $30^{\circ} \mathrm{S}$, the average $\mathrm{ML}$ 

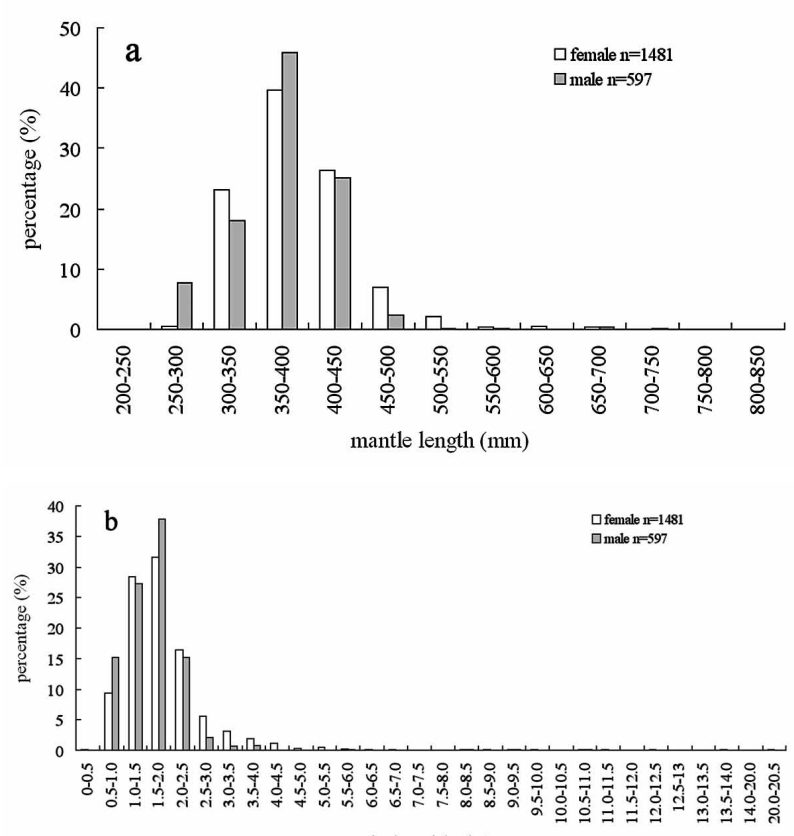

body weight $(\mathrm{kg})$

FIG. 3. - Mantle length (a) and body weight (b) compositions of female and male $D$. gigas during the three surveys off Chile between April 2006 and May 2008.

and BW ranged from $375.1 \mathrm{~mm}$ to $442.7 \mathrm{~mm}$ and from $1580 \mathrm{~g}$ to $3190 \mathrm{~g}$, and the larger size of $D$. gigas (439.1-442.7 $\mathrm{mm} \mathrm{ML)} \mathrm{was} \mathrm{distributed} \mathrm{in} \mathrm{the} \mathrm{waters}$ from $24^{\circ} \mathrm{S}$ to $30^{\circ} \mathrm{S}$. Between $37^{\circ} \mathrm{S}$ and $41^{\circ} \mathrm{S}$, the average ML and BW ranged from $365.2 \mathrm{~mm}$ to 390.7 $\mathrm{mm}$ and from 1560 to $1640 \mathrm{~g}$. However, based on the spatial distribution for longitude between $77^{\circ} \mathrm{W}$ and $85^{\circ} \mathrm{W}$, the average $\mathrm{ML}$ and $\mathrm{BW}$ were between 365.4 $\mathrm{mm}$ and $392.8 \mathrm{~mm}$ and ranged from 1580 to $1960 \mathrm{~g}$. In the area of $81^{\circ} \mathrm{W}$ to $83^{\circ} \mathrm{W}$, the size of $D$. gigas varied greatly with their $\mathrm{ML}$ and $\mathrm{BW}$, ranging from 273 to $837 \mathrm{~mm}$ and from 640 to $2040 \mathrm{~g}$, respectively. There was no such spatial pattern in size distribution along the longitudinal direction.

\section{Mantle length-body weight and mantle length- somatic body weight relationships}

The ML (cm)-BW (g) relationships (Fig. 4a) were estimated as:

$\mathrm{BW}=0.0592 \mathrm{ML}^{2.8036} \quad(\mathrm{r}=0.98, \mathrm{n}=597)$ for males, and $\mathrm{BW}=0.01476 \mathrm{ML}^{3.1446} \quad(\mathrm{r}=0.97, \mathrm{n}=1481)$ for females

The ML (cm)-somatic body weight (SBW, g) relationships (Fig. 4b) were estimated as:

$\begin{array}{lc}\text { SBW }=0.03808 \mathrm{ML}^{2.8777} & (\mathrm{r}=0.98, \mathrm{n}=597) \text { for males, and } \\ \mathrm{SBW}=0.01988 \mathrm{ML}^{3.1258} & (\mathrm{r}=0.97, \mathrm{n}=1481) \text { for females }\end{array}$

There was a significant difference in the BW-ML and SBW-ML relationships between the sexes $(\mathrm{P}<0.05$, ANCOVA).
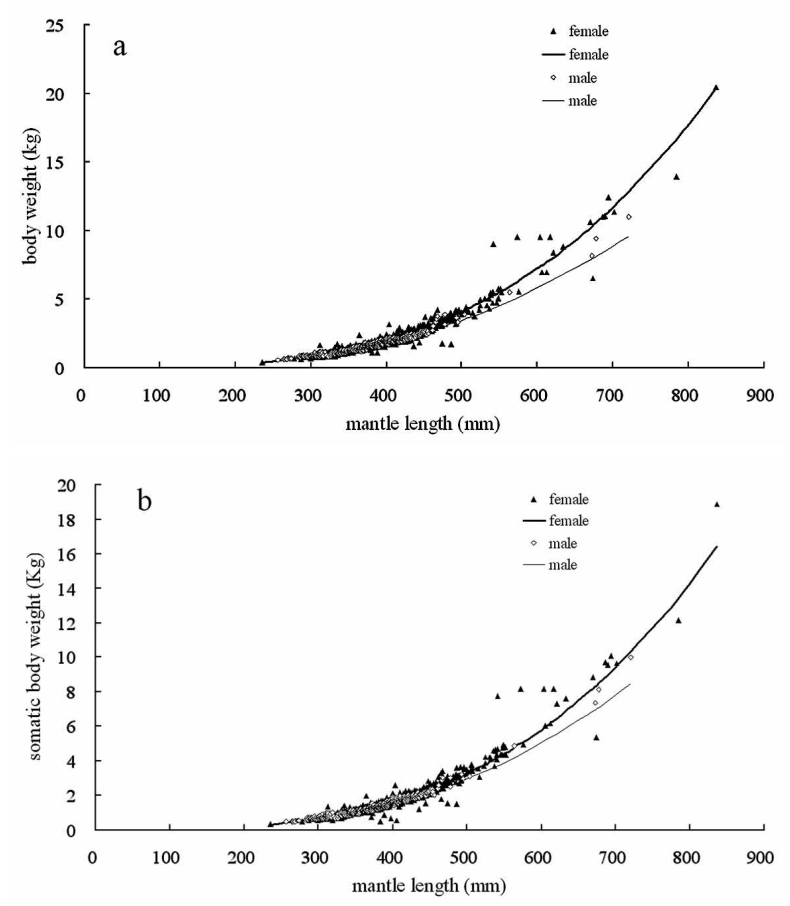

FIG. 4. - Relationships between body weight (a), somatic body weight (b) versus mantle length for female and male D. gigas off Chile.

\section{Maturity}

Maturation status was similar between the sexes (Table 4 ), with $88.4 \%$ of males in the preparatory stage (I), $4.0 \%$ in the maturing stage (III) and $2.7 \%$ in the mature stage (IV). For females, 96.1\% were immature (stages I and II) and only $3.9 \%$ were in the maturing and mature stages (III and IV; Table 4). There were no post-spawning squids (V; Table 4).

There were monthly variations in sexual maturity for both female and male squids (Table 4). From January to March, nearly $100 \%$ of males and females were in the immature stage (I), while in May and September $81.3 \%$ and $72.1 \%$ of females, and $77.8 \%$ and $82.8 \%$ of males, respectively, were in the immature stage (I) (Table 4).

The relative frequency distribution for length classes of mature individuals for females and males are described as:

males: $P_{i}=\frac{1}{1+e^{-\left(-12.222+0.019148 l_{i}\right)}} \quad\left(R^{2}=0.9564\right)$

females: $P_{i}=\frac{1}{1+e^{-\left(-6.67935+0.011817 l_{i}\right)}} \quad\left(R^{2}=0.6018\right)$

The sizes at first sexual maturity were estimated as $638 \mathrm{~mm}$ ML for females and $565 \mathrm{~mm}$ ML for males.

\section{Age composition}

The sample of D. gigas (288-517 mm ML and 637-4164 g BW) collected from January to June 2008 
TABLE 4. - Monthly composition of sexual maturity for Dosidicus gigas off Chile between April 2006 and May 2008.

\begin{tabular}{|c|c|c|c|c|c|c|c|}
\hline \multirow[t]{3}{*}{ Sex } & \multirow[t]{3}{*}{ Month } & \multirow[t]{3}{*}{ Number of samples } & \multicolumn{5}{|c|}{ Stage of sexual maturity (\%) } \\
\hline & & & & & Maturing & Mature & Post-reproduction \\
\hline & & & I & II & III & IV & V \\
\hline \multirow[t]{9}{*}{ Female } & Jan. & 122 & 99.2 & 0.0 & 0.0 & 0.8 & 0.0 \\
\hline & Feb. & 149 & 83.9 & 10.7 & 5.4 & 0.0 & 0.0 \\
\hline & Mar. & 45 & 100.0 & 0.0 & 0.0 & 0.0 & 0.0 \\
\hline & May & 416 & 81.3 & 18.7 & 0.0 & 0.0 & 0.0 \\
\hline & Jun. & 116 & 88.8 & 6.0 & 5.2 & 0.0 & 0.0 \\
\hline & Sep. & 68 & 72.1 & 20.6 & 1.5 & 5.9 & 0.0 \\
\hline & Nov. & 34 & 91.2 & 2.9 & 2.9 & 2.9 & 0.0 \\
\hline & Dec. & 47 & 93.6 & 0.0 & 2.1 & 4.3 & 0.0 \\
\hline & Overall & 997 & 88.7 & 7.4 & 2.1 & 1.8 & 0.0 \\
\hline \multirow[t]{9}{*}{ Male } & Jan. & 13 & 100.0 & 0.0 & 0.0 & 0.0 & 0.0 \\
\hline & Feb. & 39 & 94.9 & 0.0 & 5.1 & 0.0 & 0.0 \\
\hline & Mar. & 15 & 100.0 & 0.0 & 0.0 & 0.0 & 0.0 \\
\hline & May & 189 & 77.8 & 12.2 & 8.5 & 1.6 & 0.0 \\
\hline & Jun. & 64 & 87.5 & 1.6 & 9.4 & 1.6 & 0.0 \\
\hline & Sep. & 29 & 82.8 & 6.9 & 3.4 & 6.9 & 0.0 \\
\hline & Nov. & 11 & 81.8 & 18.2 & 0.0 & 0.0 & 0.0 \\
\hline & Dec. & 17 & 82.4 & 0.0 & 5.9 & 11.8 & 0.0 \\
\hline & Overall & 377 & 88.4 & 4.9 & 4.0 & 2.7 & 0.0 \\
\hline
\end{tabular}
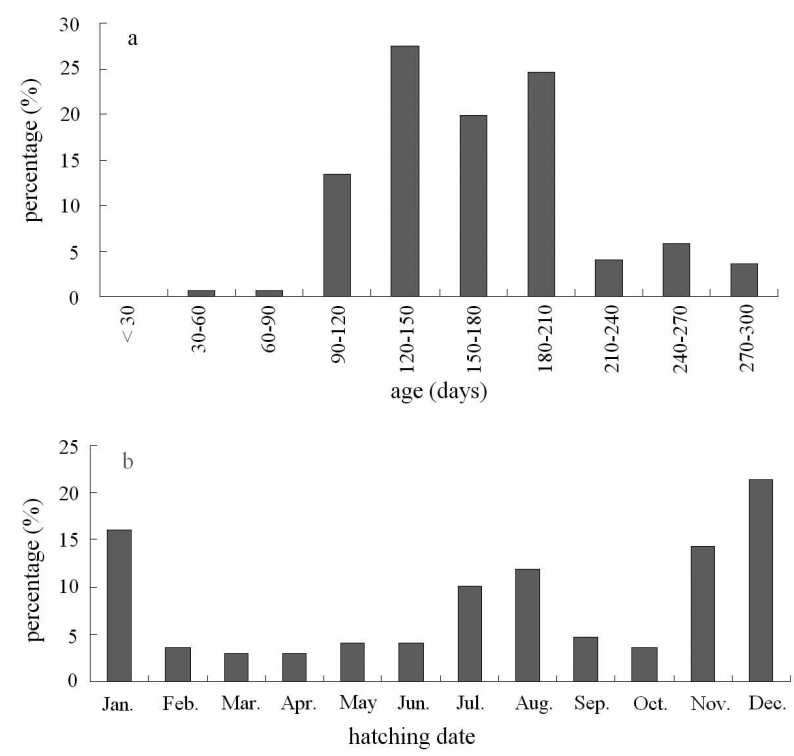

FIG. 5. - Compositions of age (a) and hatching date (b) of D. gigas off Chile.

had ages ranging from 88 to $299 \mathrm{~d}$ according to the analysis of statolith increment (Fig. 5a). All the specimens hatched from March to December 2007 and from January to February 2008 (Fig. 5b), with the majority (50.9\%) of hatching occurring from November 2007 to January 2008 . The oldest $D$. gigas in the sample grew to the size of $517 \mathrm{~mm} \mathrm{ML}$ and weighed $4163 \mathrm{~g}$.

\section{Diets}

Most of the stomachs analyzed had food remains, and on average $20.9 \%$ were empty (Fig. 6). The stomach contents included three major prey groups: fish, cephalopods and crustaceans, representing 57\%, 36\% and $7 \%$ of the stomach contents by weight, respectively. All the prey remains in the stomach contents were identified as lanternfish and D. gigas, and nearly 50\%

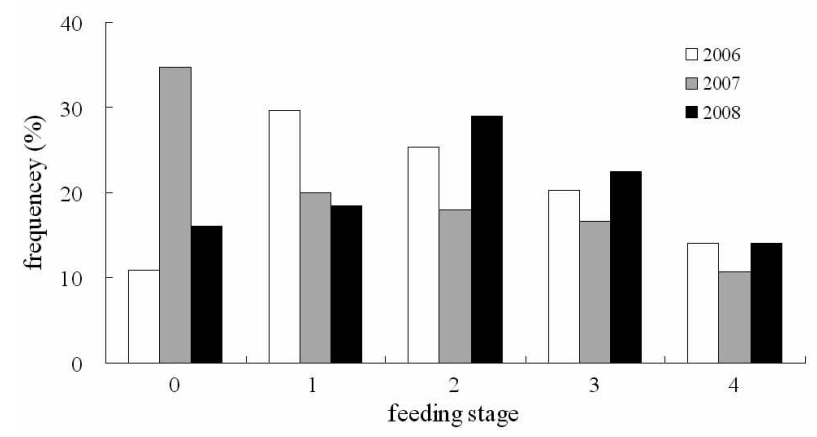

FIG. 6. - Frequencies of different feeding stages of D. gigas off Chile.

of the stomachs showed the evidence of cannibalism. However, cannibalism was much greater for the squids caught in the light field near the survey vessel, and the fish, Chilean jack mackerel (Trachurus murphyi) was often attacked by large-sized $D$. gigas around the squid jigging vessels in the southern waters $\left(38^{\circ}-41^{\circ} \mathrm{S}\right)$.

About $67 \%$ of the stomachs were less than half full, and the fullness of stages 1 and 2 consisted of $20.9 \%$ and $25.1 \%$ of the total samples (Fig. 6), respectively.

\section{DISCUSSION}

D. gigas were found to be widely present in the survey area, but the majority of catch was located in the areas defined by $37-40^{\circ} \mathrm{S}$ and $78^{\circ} 30^{\prime}-81^{\circ} \mathrm{W}$ and by $23^{\circ} 30^{\prime}-28^{\circ} \mathrm{S}$ and $75^{\circ} 30^{\prime}-78^{\circ} \mathrm{W}$. This is consistent with previous studies (Ibáñez and Cubillos, 2007). The distribution of D. gigas is considered to be closely related to sea surface temperature (SST). This study suggests that the favourable SST for D. gigas ranges from 17.5 to $21^{\circ} \mathrm{C}$ on the northern fishing ground $\left(20^{\circ}-30^{\circ} \mathrm{S}\right)$ and from 14 to $16^{\circ} \mathrm{C}$ on the southern fishing ground (37$41^{\circ} \mathrm{S}$ ). This is consistent with the results obtained for other areas included in previous studies. For example, the high concentration of D. gigas took place in Peru- 
vian waters with SST between 17 and $22^{\circ} \mathrm{C}$ (Waluda et al., 2006). Thus, the result of this study supports the hypothesis that SST is critical in influencing the spatial distributon of D. gigas (Anderson and Rodhouse, 2001; Nigmatullin et al., 2001).

The recent catch of $D$. gigas along the Chilean coast between 2002 and 2005 has been reported to increase (Zúñiga et al., 2008), which is consistent with the report in the waters of $40-45^{\circ} \mathrm{S}$ and $100-75^{\circ} \mathrm{W}$ by the Chinese large mid-water trawler targeting jack mackerel (Trachurus murphyi) and the Chinese squid jigging survey from 2006 to 2008. This may suggest that there is a local population of D. gigas in Chilean waters (Zúñiga et al., 2008). More studies, however, need to be done to examine the influence of SST on the spatial distribution and migration of $D$. gigas and the possible existence of a local population in the waters off Chile.

The intraspecific structure of $D$. gigas tends to be complicated (Nigmatullin et al., 2001), and there has been no consensus on population structure. The ML composition of catch is often considered as an indicator of population structure. The dominant group observed in the survey was squid of 350-450 mm ML for males and 350-450 $\mathrm{mm}$ ML for females. In the oceanic waters off central-southern Chile, mature medium-sized squids were found in the austral winter (July-September), mature medium-sized and large-sized squids in the austral spring (October-December), and small immature and mature medium-sized squids in the austral summer (January-February) (Ibáñez and Cubillos, 2007). The size of our sample ranged from 236 to 837 $\mathrm{mm}$ ML, probably covering the possible size range of this species. Ibáñez and Cubillos (2007) postulated that the spatial and temporal changes in size structure of D. gigas off central-southern Chile were probably due to the existence of a migratory strategy of the species in the study area. Based on the hatching-date distribution from the collected sample, we concluded that there were at least two spawning groups, a summer group (hatching from June to August) and a winter group (hatching from December to February of the next year) (Fig. 5b). This result is consistent with that reported in some studies (González and Chong, 2006; Zúñiga et al., 2008), it contradicts the results reported by Nigmatullin et al. (2001). Lack of evidence in this study for the presence of the small-size group described in Nigmatullin et al. (2001) might result from the low catchability of small squid by the large jiggers used in this study.

Of the sample collected in three surveys, there were more females than males and the averaged sex ratio (M:F) was 1: 2.48. In the survey, the big squid jigger with three lines of $1.6 \mathrm{~mm}$ diameter was used. As a result, the small individuals of D. gigas, mostly males, might have less likelihood of being caught than the large individuals. Thus, the observed skewed sex ratio may result from the selectivity of fishing gear. In Peruvian waters, Tafur et al. (2001) reported that females were always more than males during the study period, and the averaged sex ratio (M:F) was 1: 2.85, comparable with that of this study.

This study found that D. gigas males matured at smaller sizes than females, which is normally described as a characteristic of cephalopods in general (González and Guerra, 1996). The range of sizes for mature males and females in this study is different from that found in the oceanic waters off Peru (Nesis, 1983) and in Peruvian waters (Tafur et al., 2001).

The sample of D. gigas (288-517 mm ML and 637-4164 g BW) collected from January to June 2008 had ages ranging from 88 to $299 \mathrm{~d}$ according to the increment of statoliths (Fig. 5a). The oldest squid in the sample grew to the size of $517 \mathrm{~mm} \mathrm{ML}$ and weighed $4163 \mathrm{~g}$. Ages of D. gagis have been studied using two different methods: cohort analysis using length-frequency distributions (Ehrhardt et al., 1983) and ageing analysis using statolith gladii techniques (Arkhipkin and Murzov, 1987; Masuda et al., 1998; Argüelles et al., 2001). D. gagis is confirmed to grow fast, reaching 700-750 $\mathrm{mm}$ ML by the end of age 1 (Ehrhardt et al., 1983). The longevity of all three groups of D. gigas is about 1 year, but some huge specimens $(>750 \mathrm{~mm}$ $\mathrm{ML})$ of the large group could live for up to 1.5-2 years (Nigmatullin et al., 2001; Wang and Chen, 2005).

We found that all the individuals examined were hatched from March 2007 to February 2008. Therefore, D. gigas were likely to spawn all year around, and the peak spawning time in the study areas was from November 2007 to January 2008. There is a distinct peak in spawning during spring and summer in the southern hemisphere (Nigmatullin et al., 2001; Taipe et al., 2001), and a secondary peak from July to August (Tafur and Rabi, 1997; Tafur et al., 2001).

The parameters of the length-weight relationships were different from those found by Chong et al. (2005) for central-northern Chile in 1993 and by Ibáñez and Cubillos (2007) for central-southern Chile from 2003 to 2004. The average weight of females was heavier than that of males at a given ML, and the difference increased in specimens larger than $450 \mathrm{~mm}$ ML.

D. gigas is and opportunistic predator whose feeding spectrum differs between sizes and regions (Wang and Chen, 2005). The stomachs contained fish, cephalopods and crustaceans, mainly lanternfish and D. gigas. More than $50 \%$ of the stomachs had evidence of cannibalism for D. gigas. Nigmatullin et al. (2001) found that the feeding spectrum of D. gigas changed with their sizes, from macroplanktonic invertebrates and fish fry (in juveniles) to fish and squid (in adults). Near-surface lanternfish completely predominate among fish preys, and $D$. gigas are predominant among squid preys. Diets also varied spatially, mainly determined by food availability in the ecosystem. For example, the diets were dominated by mesopelagic fishes such as Benthosema panamense, Triphoturus mexicanus, and Vinciguerria lucetia in the Gulf of California and adjacent waters (Markaida and Sosa-Nishizaki., 2003), which is different from teh findings of this study. 
In this study, we obtained results on some key aspects of the fisheries biology of D. gigas off Chile. The information obtained is critical to improving our understanding of the spatial variability of key biological processes for a species with such a wide distribution. To further improve our understanding of the fisheries biology of $D$. gigas off Chile, we need to conduct a comparative study to quantify differences in fisheries biology between this squid population and squid populations inhabiting Peruvian waters, Californian waters and Chilean coastal waters. Key environmental variables influencing the biological processes should be identified and quantified.

\section{ACKNOWLEDGEMENTS}

The support for the three scientific surveys made by New Century No 52, Xin Jieli No 8 and Zhe Yunyu No 807 is gratefully acknowledged. This work was funded by the National Nature Science Foundation (NSFC40876090), the "Shu Guang" project (08GG14) of the Shanghai Municipal Education Commission, the Specialized Research Fund for the Doctoral Programme of Higher Education (20093104110002) and the Shanghai Leading Academic Discipline Project (Project S30702). Y. Chen's involvement in the project was supported by the Shanghai Dongfeng Scholar Programme.

\section{REFERENCES}

Anderson, C.I.H. and P.G. Rodhouse. - 2001. Life cycles, oceanography and variability: ommastrephid squid in variable oceanographic environments. Fish. Res., 54: 133-143.

Argüelles, J., P.G. Rodhouse, P. Villegas and G. Castillo. - 2001. Age, growth and population structure of the jumbo flying squid Dosidicus gigas in Peruvian waters. Fish. Res., 54: 51-61.

Argüelles, J., R. Tafur, A. Taipe, V. Piero, F. Keyl, D. Noel and S. Martin. - 2008. Size increment of jumbo flying squid Dosidicus gigas mature females in Peruvian waters, 1989-2004. Prog. Oceanogr., 79(2-4): 308-312.

Arkhipkin, A.I. - 1989. Age and growth of squids of the family Ommastrephidae. Ph.D. thesis. Shishov Institute of oceanography, Moscow, pp. 25 (in Russian).

Arkhipkin, A.I. - 1991. Methods for cephalopod age and growth studies with emphasis on statolith ageing techniques. Squid Age Determination Using Statoliths. Proc. Int. Workshop, Mazara del Vallo, Italy, 9-14 October 1989. In: P. Jereb, S. Ragonese, S. von Boletzky (eds.), Note Techniche e Reprints dell'Istituto di Tecnologia della Pesca e del Pescato. Spec. publ., No. 1, Mazara del Vallo, Italy. C. pp. 11-17.

Arkhipkin, A.I. and S.A. Murzov. - 1987. Age and growth patterns of Dosidicus squid (Dosidicus gigas) (Ommastrephidae). In: B.G. Ivanov (ed.), Present state of fishery for squids and prospects of its development. VNIRO Press, Moscow, pp. 107-123 (1986) (in Russian, English Abstract).

Bazanov, S.I. - 1987. On the cause of coexistence in mixed shoals of two sympatric epipelagic squids of the family Ommastrephidae in Southeastern Pacific. Inform. Bull. Freshwater Biol., 73: 48-51 (in Russian).

Chen, X. J., B. L. Liu and Y. Chen. - 2008. A review of the development of Chinese distant-water squid jigging fisheries. Fish. Res., 89: 211-221.

Chen, X.J., B.L. Liu, S.Q. Tian, W.G. Qian and X. H. Zhao. -2007. Fishery biology of purpleback squid, Sthenoteuthis oualaniensis, in the northwest Indian Ocean., Fish. Res., 83(1): 98-104.

Chong, J., C. Oyarzún, R. Galleguillos, E. Tarifeño, R.D. Sepúlveda and C.M. Ibáñez. - 2005. Parámetros biológico-pesqueros de la jibia, Dosidicus gigas (Orbigny, 1835) (Cephalopoda: Ommastrephidae) frente a la costa de Chile central $\left(29^{\circ} \mathrm{S}\right.$ y $\left.40^{\circ} \mathrm{S}\right)$ durante el periodo 1993-1994. Gayana, 69: 319-328.

Ehrhardt, N.M., P. Jacquemin, F. García, G. Gonzáles, J.M. López, J. Ortiz and A. Solís. - 1983. Summary of the fishery and biology of the jumbo squid (Dosidicus gigas) in the Gulf of California, Mexico. Mem. Natl. Mus. Victoria, 44: 305-311.

Garcia-Tello, P. - 1965. Utilización de la mandíbula inferior de la jibia Dosidicus gigas (D’Orbigny) en el cálculo de su peso total (Molusca, Cephalopoda, Ommastrephidae). Rev. Biol. Mar., 12: $1-3$.

González, A.F. and A. Guerra. - 1996. Reproductive biology of the short-finned squid Illex coindetii (Cephalopoda, Ommastrephidae) of the northeastern Atlantic. Sarsia, 81: 107-118.

González P. and J. Chong. - 2006. Biología reproductiva de Dosidicus gigas D’Orbigny 1835 (Cephalopoda, Ommastrephidae) en la zona norte-centro de Chile. Gayana, 70(2): 237-244.

Hu, Z.M., X.J. Chen and Y.Q. Zhou. - 2009. Review on Fishery Biology of Jumbo flying squid Dosidicus gigas in the Southeast Pacific Ocean. J. Guangdong Ocean Univ., 29(3): 98-102.

Ibáñez, C.M. and L.A.Cubillos. - 2007. Seasonal variation in the length structure and reproductive condition of the jumbo squid Dosidicus gigas (d'Orbigny, 1835) off central-south Chile. Sci. Mar., 71(1): 123-128.

Keyl, F., J. Argüelles, L. Mariátegui, R. Tafur, M. Wolff and C. Yamashiro. - 2008. A hypothesis on range expansion and spatio-temporal shifts in size-at-maturity of jumbo squid (Dosidicus gigas) in the Eastern Pacific Ocean. CalCOFI Rep., 49: 119-128.

Lipinski, M. -1979. Universal maturity scale for the commercially important squids. The results of maturity classification of the $\mathrm{Il}$ lex illecebrosus population for the years 1973-1977. Int. Comm. N. Atl. Fish. Res. Doc., 70/2/38, Ser. 5364, Canada.

Markaida, U. -2006. Population structure and reproductive biology of jumbo squid Dosidicus gigas from the Gulf of California after the 1997-1998 El Niño event. Fish. Res., 79: 28-37.

Markaida, U. and O. Sosa-Nishizaki. - 2003. Food and feeding habits of jumbo squid Dosidicus gigas (Cephalopoda: Ommastrephidae) from the Gulf of California, Mexico. J. Mar. Biol. Assoc. U.K. 83(3): 507-522.

Masuda, S., K. Yokawa, A.Yatsu and S. Kawahara. - 1998. Growth and population structure of Dosidicus gigas in the Southeastern Pacific Ocean. In: T. Okutani (ed.) Contributed papers to International symposium on large pelagic squids, July 18-19, 1996, JAMARC, Tokyo, pp. 107-118.

Nesis, K.N. - 1983. Dosidicus gigas. In: P.R. Boyle (ed.), Cephalopod Life Cycles: Species Accounts, vol. I. pp. 215-231. Academic Press.

Nigmatullin, Ch.M. - 1999. Fishery ecology of jumbo squid Dosidicus gigas in the EEZ of Nicaragua. In: A.E. Tresierra Aguilar, Z.G. Culquichicon Malpica (eds.), First International Symposium on Pacific Squids. VIII Congreso Latinoamericano sobre Ciencias del Mar, Trujillo, Peru, 17-21 de Octubre, 1999. Libro de Resumenes Ampliados, tomo I, pp. 283.

Nigmatullin, Ch.M., K.N. Nesis and A.I. Arkhipkin. - 2001. A review of the biology of the jumbo squid Dosidicus gigas (Cephalopoda: Ommastrephidae). Fish. Res., 54(1): 9-19.

Ricker, W.E. -1975. Computation and interpretation of biological statistics of fish populations. Bull. Fish. Res. B. Can., 191: 382.

Rocha, F. and M. Vega. - 2003. Overview of cephalopod fisheries in Chilean waters. Fish. Res., 60: 151-159.

Rocha, F. -1997. Cephalopods in Chilean waters: a review. Malacol. Rev., 30: 101-113.

Tafur, R. and M. Rabí. - 1997. Reproduction of the jumbo squid Dosidicus gigas (Cephalopoda: Ommastrephidae) off Peruvian coast. Sci. Mar., 61: 33-37.

Tafur, R., P. Villegas, M. Rabi and C. Yamashiro. - 2001. Dynamics of maturation, seasonality of reproduction and spawning grounds of the jumbo squid Dosidicus gigas (Cephalopoda: Ommastrephidae) in Peruvian waters. Fish. Res., 54: 33-50.

Taipe, A., C. Yamashiro, L. Mariategui, P. Rojas and C. Roque. - 2001. Distribution and concentrations of jumbo flying squid (Dosidicus gigas) off the Peruvian coast between 1991 and 1999. Fish. Res., 5: 21-23.

Waluda, C.M., C. Yamashiro and P.G. Rodhouse. - 2006. Influence of the ENSO cycle on the light-fishery for Dosidicus gigas 
in the Peru Current: an analysis of remotely sensed data. Fish. Res., 79: 56-63.

Wang, Y.G. and X.J. Chen. - 2005. The resource and biology of economic oceanic squid in the world. Ocean Press, Beijing.

Wormuth, W.S. - 1970. Morphometry of two species of the family Ommastrephidae. The Veliger, 13: 139-144.

Ye, X.C. - 2002. Conclusion and analysis on the experimental fishing of Dosidicus gigas in the offshore of Peru and Costa Rica in 2001. Mar. Fish., 4: 165-168.

Ye, X.C. and X.J. Chen. - 2007. Study of size composition and sex maturity of jumbo flying squid (Dosidicus gigas) in the waters off Peru. J. Shanghai Fish. Univ., 16(4): 347-350.

Zúñiga, M.J., L.A. Cubillos and C. Ibáñez. - 2008. A regular pattern of periodicity in the monthly catch of jumbo squid (Dosidicus gigas) along the Chilean coast (2002-2005). Cienc. Mar., 34(1): 91-99.

Scient. ed.: A. Guerra.

Received October 1, 2009. Accepted February 2, 2010.

Published online July 6. 2010. 